\title{
Feasibility Study using the PMBOK® Methodology
}

\section{Aurora Díaz Cuevas ${ }^{1}$, Patricia Lyssett Bellato Gil², Verónica Flores Sánchez ${ }^{3}$, Arely Vallejo Hernández ${ }^{4}$}

\author{
${ }^{1}$ Department of proyect, Grant Prideco S de R. L de C.V \\ Email: aurora.diazcuevas17@nov.com \\ ${ }^{2}$ Department of DNM, Universidad Tecnológica del Centro de Veracruz, Veracurz, México \\ Email: lyssett.bellato@utcv.edu.mx \\ ${ }^{3}$ Department of IMI, Universidad Tecnológica del Centro de Veracruz, Veracurz, México \\ Email: calidad.utcv@gmail.com \\ ${ }^{4}$ Department of IMI, Universidad Tecnológica del Centro de Veracruz, Veracurz, México \\ Email: arely.vallejo@utcv.edu.mx
}

\begin{abstract}
In 1969 Martin Barnes opened the debate a lot about what is the best way to describe the fundamental limitations that underpin the success of the project.

This paper develops a project integration model "Beyoutiful Esthetics" through the PMBOK® methodology.

The objective in this document is to present the case of this model and demonstrate the way to evaluate the project in the delivery of successful results as part of the development of the $P M B O K \circledR$ model, in the area of beauty culture.
\end{abstract}

Keywords- PMВОК®, Project management, beauty culture.

\section{INTRODUCTION}

Numerous investments, as well as professionalization in large companies, which show the relevance of Project Management, which involves feasibility, planning, costs, compatibility, integration and maintenance, increasing the search for skills in the management of new resources. In considering the importance of these relevant aspects and of this concurrent movement, the inspiration for the elaboration of this paper.

With the aim of spreading the concept and the importance of the management of the integration of corporate projects and drawing a panorama of integration in the future of business, project management is increasingly used also in small projects, with teams, sometimes, multifunctional, which are mobilized for execution.

Maintaining quality and control of various projects in progress is a complex task. The company that can reconcile all the necessary links for the realization of the works of form organized and planned and is concerned with project management: avoid surprises, anticipate unfavorable situations, work with budgets, streamline decisions, improve control, optimize the allocation of resources and document the process.

The importance of project management is reinforced by DAVIS et al (1989), which indicates a greater opportunity to influence the cost of producing a business in feasibility study phase, briefing and project, that is, in the planning phase.

During the development of a project, much is said about the success it will have in the near future, for this there are conventional methodologies that help project management, however they have been questioned (Weaver, 2012).

PMBOK® (Project Management Body), is a methodology that develops in the procedure to develop successful projects

When an innovative idea emerges comes with the risk of failure, entrepreneurs do not always decide to take risks to achieve their business idea.

According to the National Entrepreneur Institute in Mexico, only $19 \%$ of start-ups in the country are women (López, 2016).

The evaluation of the financial viability of a new "BeYOUtiful" business model is presented below. That provides aesthetic services and children's play area.

\section{OBJECTIVES}

Analyze the financial viability of an aesthetic investment in the city of Boca del Rio, Veracruz, Mexico.

Specific objectives

Verify if the business is viable from the economic point of view in accordance with the financial parameters of acceptance of projects.

Evaluate the investment and the recovery period of it. Delimit the technical bases to execute the project. 


\section{RESEARCH PROPOSAL}

In order to provide a structured version of the process to carry out the development of the project it is necessary to subdivide the work into smaller and easier to manage components.

The project was divided into 5 stages, each one represented by a "hito".

Subsequently, each of these parts were subdivided into tasks, and the working block structure was formed as shows below:

$\begin{array}{ll}\text { 1. } & \text { Calculations Financial } \\ \text { 2. } & \text { Preparation of financial statements basic } \\ \text { 3. } & \text { Calculation of Reasons Financial } \\ \text { 4. } & \text { Current Value Net (VAN) } \\ \text { 5. } & \text { Internal Rate return } \\ \text { 6. } & \text { Analysis e interpretation Financial } \\ \text { 7. } & \text { Proposal }\end{array}$

It is important to mention that the financial evaluation of the case study project has been carried out in Mexican pesos.

Table.1: Analysis of costs

\begin{tabular}{ll}
\hline Description & Quantity \\
\hline Inventory & $\$ 30,000$ \\
Fixed assets & $\$ 140,000$ \\
Working capital & $\$ 76,000$ \\
Total & $\$ 246,000$
\end{tabular}

In table one the project costs are shown. The financing sources of the project are:

1. Bank institution $\$ 100,000$

2. Suppliers $\$ 146,000$

With a weighted cost of capital of $9.63 \%$. It is worth mentioning that the cost of capital of the banking institution is $12 \%$ and suppliers of $4 \%$.

The annual cost of operation budget considers the salary of two people who support the stylist, the salary of the stylist, the salary of the master stylist, the depression and the materials. In addition, administration costs include water and electricity services, without leaving out the lease and paperwork.

Table 2 contains the operation cost of the project and the projection of sales in the next 3 years, it is estimated that the net income in the first year will be 517560 Mexican pesos, for the year two 370580 and in year three 374780 .

With the previous cash flow projection proceeds to calculate the net present value or net present value (VAN). The net present value (VAN) is a financial indicator used to determine the viability of a project. If after measuring the flows of future income and expenses and discounting the initial investment, some profit remains, the project is viable. (Ross, 2016)

Table.2: Projected Income Statement (3 years)

\begin{tabular}{lrrr}
\hline Description & $\mathbf{1}$ & $\mathbf{2}$ & $\mathbf{3}$ \\
\hline Sales & 1620000 & 1620000 & 1620000 \\
Cost of sales & 647600 & 647600 & 647600 \\
Gross profit & 972400 & 972400 & 972400 \\
Expenses of Administration & 437000 & 437000 & 437000 \\
and sales & 535400 & 535400 & 535400 \\
Utility of operation & 17840 & 6000 & 0 \\
Interests financial & 517560 & 529400 & 535400 \\
Utility before taxes & 0 & 158820 & 160620 \\
Taxes & 517560 & 370580 & 374780 \\
Net Income & & & \\
\end{tabular}

VAN $<0$ the project is not profitable. When the investment is greater than the BNA (NPV negative or less than 0) it means that the TD is not satisfied.

$\mathrm{VAN}=0$ the project is profitable, because TD gain is already incorporated.

When the BNA is equal to the investment (VAN equal to $0)$, the TD has been met.

VAN $>0$ the project is profitable. When the BNA is greater than the investment (NPV greater than 0), this rate has been met and, in addition, an additional gain or benefit has been generated.

According to cash flows and estimated interest, the Net Present Value of the Project is \$1,377,908 Mexican pesos. VAN $>0$ the project is profitable. When the BNA is greater than the investment (NPV greater than 0), this rate has been met, and an additional gain or benefit has been generated.

The period of recovery of the investment will be in year 1, in this year you have the benefit that will not be paid tax.

The Internal Rate of Return (TIR) is the interest rate or return offered by an investment. That is, it is the percentage of profit or loss that an investment will have for the amounts that have not been withdrawn from the project (Gitman, 2003).

The selection criteria will be the following where " $k$ " is the discount rate of flows chosen for the calculation of the VAN:

If $T I R>k$, the investment project will be accepted. In this case, the internal rate of return that is obtained is higher than the minimum rate of return required for the investment.

If $\mathrm{TIR}=\mathrm{k}$, one would be in a situation similar to the one that occurred when the NPV was equal to zero. In this situation, the investment can be carried out if the competitive position of the company improves and there are no more favorable alternatives. 
If $\mathrm{TIR}<\mathrm{k}$, the project must be rejected. The minimum profitability that we ask of the investment is not reached.

TIR: $199 \%$

Net TIR $189 \%$

The financial ratios are indicators used in the world of finance to measure or quantify the economic and financial reality of a company or unit evaluated, and its ability to assume the different obligations to take charge in order to develop its corporate purpose (García, 2015).

\section{Reasons for indebtedness.}

The reasons for indebtedness allow to identify the degree of indebtedness that the company has and its capacity to assume its liabilities. Among the indicators used are the following:

\section{Debt ratio.}

Measures the proportion of assets that are financed by third parties.

Recall that the assets of a company are financed either by partners or by third parties (suppliers or creditors).

It is determined by dividing the total liabilities by total assets.

In the first year the indebtedness will be $100 \%$.

\section{Reasons for profitability}

These reasons are intended to measure the level or degree of profitability that the company obtains either with respect to sales, with respect to the amount of the assets of the company or with respect to the capital contributed by the partners.

The most indicators common are the following:

Net profit margin.

All operational chargeable expenses are subtracted from the sales value including any taxes that may apply.

\section{CONCLUSION}

Once the financial viability study of the Beyoutiful aesthetics project in Boca del Río has been completed, sufficient and sufficient information is available to reach the following conclusions:

1. There is a very high potential market.

2. According to a conservative scenario to which the project was subjected during the financial and economic analysis, it was economically viable, since the profitability offered by the project (TIR) was greater than the minimum profitability required by the investor (TREMA) 16\%, result corroborated by the Net Present Value (VAN) that is positive.

3. The investment recovery period will be in year 1, you have the benefit that tax will not be paid.

4. The economic feasibility of the project is maintained, even in front of possible variations, sale prices, quantities and operating expenses, as demonstrated in the simulation of scenarios.

\section{RECOMMENDATIONS}

As this is a highly consumable service in the market, it is recommended to implement a marketing plan that discloses the quality service offered and implement standardized services in the state through a system of Franchises that through the financial study shows its viability and the guarantee to be an investment option to those who intend to undertake or diversify their businesses.

\section{REFERENCES}

[1] Barber, L. (2018). Small Business Engagement Office.

[2] Breth, R. (1974). Las comunicaciones en la dirección de empresas. España: Fondo Educativo Interamericano.

[3] Chiavenato, I. (2006). Introducción a la Teoría General de la Administración ( $7^{\text {a }}$ ed.). México: McGraw Hill.

[4] García, P. V. (2015). Análisis Financiero. Un enfoque integral. México: Patria.

[5] Gibson, J., Donnelly, J., \& Konopaske, R. (2011). Organizaciones. Comportamiento, estructura y procesos (13 ${ }^{\mathrm{a}}$ ed.). México: McGraw Hill.

[6] Gido, J., \& Clements, J. (2012). Administración exitosa de proyectos ( $5^{\mathrm{a}}$ ed.). México: Cengage Learning.

[7] Gitman, L. (2003). Principios de administración financiera. México: Pearson.

[8] Hellriegel, D., Jackson, S., \& Slocum, J. (2002). Administración. Un enfoque basado en competencias. México: S.A. Ediciones Paraninfo.

[9] Instituto Nacional de Estadística y Geografía. (2011). Micro, pequeña, mediana y gran empresa. Estratificación de los establecimientos. Retrieved Marzo 25, 2017, from Censos económicos 2009: http://www.inegi.org.mx/est/contenidos/espanol/proy ectos/censos/ce2009/pdf/Mono_Micro_peque_media na.pdf

[10] Jones, G. (2013). Teoría organizacional, diseño y cambio en las organizaciones ( $7^{\mathrm{a}}$ ed.). México: Pearson.

[11] Koontz, H., Weihrich, H., \& Cannice, M. (2012). Administración. Una perspectiva global y empresarial. (14 ed.). México: McGraw Hill.

[12] López, A. (2016). Tecnológico de Monterrey.

[13] Loya, S. (2013). Liderazgo en el comportamiento organizacional. México: Trillas. Project Management Institute, Inc. (2013). Guía de los fundamentos para la dirección de proyectos (Guía del PMBOK) (5 $5^{\mathrm{a}}$ ed.). Estados Unidos: PMI Publications.

[14] Ross, S. (2016). Finanzas Corporativas. México: Mc Graw Hill. 